\title{
Folkehøjskoler i Bangladesh
}

\author{
Af Torstein Balle
}

K.E. Bugge: "Folkehøjskoler i Bangladesh", Odense Universitetsforlag 2000, 96 s., $125 \mathrm{kr}$.

Selv om K.E. Bugges bog Folkehøjskoler i Bangladesh er kommet på Odense Universitetsforlag, er bogen oprindelig tænkt at skulle komme som én i en serie af skrifter på Kroghs Forlag. Skrift-serien, som blev udgivet af forskningscentret Nornesalen, består af tre udgivelser: Grundtvigs skoletanker i Japan, Filippinerne og Israel (af Lilian Zøllner, 1994), Grundtvigs skoletanker i USA, Argentina og Chile.(af Lilian Zøllner, 1977) og Canada og Grundtvig (af K.E. Bugge, 1997). Nornesalen ophørte af forskellige grunde, som ikke skal uddybes her, med at eksistere, og skriftserien sluttede sine udgivelser. Heldigvis fik K.E. Bugge alligevel mulighed for at udgive Folkehøjskoler $i$ Bangladesh. Bogen indeholder nemlig efter min mening nogle vigtige perspektiver og overvejelser over forholdet mellem Grundtvigs tænkning om skole og liv og den måde, inspirationen herfra omsætter sig på i kulturer uden for Europa. Perspektiver og overvejelser, som de øvrige tre bøger mangler - især de to førstnævnte.

Den oprindelige skriftseries idé var at give »en samlet beskrivelse af Grundtvigs skoletankers virkningshistorie uden for Norden " ${ }^{1}$ (min understregning). Dette har de hidtidige udgivelser levet op til. De er beskrivelser, mere end de er analyser. Men selv om Bugge i denne seneste udgivelse fastholder målsætningen »at kortlogge udbredelsen af Grundtvigs skoletanker uden for Skandinavien “' ${ }^{2}$, så bliver bogen mere end en kortlægning og en beskrivelse. Den sidste tredjedel af bogen er nemlig under overskriften Perspektiver til Grundtvig en spændende analyse af forholdet mellem Grundtvigs skoletanker og den måde, de folkehøjskoleinspirerede initiativer i Bangladesh praktiseres på.

Bogens første to tredjedele er indholdsmæssigt opdelt i tre afsnit: 1) en kort orientering om landet Bangladesh, 2) en beskrivelse af de såkaldte gonobidyalayaer (nogle højskoleinspirerede voksenundervisningsskoler) og 3) en beskrivelse af andre skoleprojekter, der er beslægtede med gonobidyalayaer.

Bogen indledes altså (i øvrigt på samme måde som de tre andre bøger i serien) med et kapitel om landet Bangladesh. Det er en indføring i landets historie og aktuelle situation, og det er en god og relevant indforring med henblik på at forstå den del af Bangladesh, som bogen beskæftiger sig med - nemlig landets voksenundervisningssystem. Især understreges det særkende ved Bangladesh, at det er en meget homogen kultur båret oppe af ét sprog og én dominerende religion. Dette særkende får også betydning for Bugges analyse af undervisningsprojekternes praksis og teori set $i$ relation til Grundtvig og den danske højskole. $\mathrm{Og}$ særkendet trækkes også frem i en sammenligning med de højskoleinitiativer, der er etableret i nabolandet Indien, hvor sprogene jo er mange og religionerne ligeså. Det er Bugges opfattelse, at netop Bangladeshes monokulturelle omstændighed gør, at der trods landets meget alvorlige sociale situation kan knyttes et større håb om positiv udvikling til Bangladesh end til udviklingen i In- 
dien og Afrika, hvor religiøse, kulturelle og stammemæssige konflikter gør forandring næsten umulig. Når man ser fattigdommen og nøden i Bangladesh bliver man, synes jeg, faktisk så overvældet, at håbet ikke er det første, man făr i tankerne. Også derfor er det en god og nyttig iagttagelse, Bugge gør og giver videre.

Bogens andet og tredje hovedafsnit er som sagt helliget en præsentation af de undervisningsprojekter i Bangladesh, som er inspireret af de danske folkehøjskoler, eller som minder om disse projekter. Især bliver de såkaldte gonobidyalayaer beskrevet. Gonobidyalaya betyder folkets skoler på bangla, idet gono betyder folk og dyalaya betyder skole. Siden oktober 1981 har Danmark gennem DANIDA givet støtte til disse skoler, hvoraf der er fem i Bangladesh. I flere år nu har bevillingen fra DANIDA været administreret gennem FFD, hvilket har underbygget disse gonobidyalayaers inspiration fra folkehøjskolens idé.

Bortset fra en lidt sparsom beskrivelse af Panchagram Gonobidyalaya ${ }^{3}$ giver Bugge en meget grundig og detaljeret beskrivelse af disse bengalske højskoleprojekter - både af det konkrete skoleliv, der finder sted på skolerne, og af ideen og den pædagogiske tænkning bag skolernes praksis. Hele tiden henviser Bugge til relevant kildemateriale, når han drager sine konklusioner. Ambitionen er tydeligvis, at beskrivelsen skal fremstå videnskabelig - dvs. systematisk og kildefunderet - og denne ambition opnås bestemt. Ofte så meget, at man ind imellem kan savne et indblik i Bugges personlige oplevelse af Bangladesh og gonobidyalayaerne - eller i det mindste nogle beskrivelser, der fanger den mere følelsesmæssige eller psykologiske side af livet på skolerne.

Den videnskabelige ambition og den dermed nødvendige (men for store) afstand til forsknings-genstanden kommer f.eks. også til udtryk ved, at Bugge i bogen omtaler sig selv som »intervieweren $\ll$. Jeg tror, Bugge er mere engageret i sagen end blot at være "interviewer", og en inddragelse af den personlige oplevelse ville efter min mening ikke gøre bogen mindre videnskabeligt lødig. Men det er selvfølgelig et valg fra Bugges side af én af i hvert fald to mulige positioner i forbindelse med videnskabelig fremstilling: en strengt faktuelt beskrivende og en mere oplevelsesorienteret. Hvad man end vælger, er det vigtigste naturligvis, at præmissen er klar-og den er man ikke i tvivl om hos Bugge.

Også afsnittet om de gonobidyalya-beslægtede initiativer er meget oplysende og giver et billede af, at de grundtvigske tanker om skole har inspireret bredt i Bangladesh.

Bogens absolut mest interessante afsnit er som allerede nævnt det sidste store afsnit med overskriften »Perspektiver til Grundtvig". Bugge præsenterer til en begyndelse to store evalueringsrapporter udarbejdet til DANIDA. Heri redegøres for nogle spændende sammenhænge mellem danske folkehøjskoler og gonobidyalayaerne, og ligheder og forskelle mellem dem trækkes frem. Derefter stiller Bugge spørgsmålet: Hvad sker der med Grundtvigs paedagogiske tanker, $i$ det øjeblik de indarbejdes $i$ en udviklingssammenhoeng, dvs. $i$ en kontekst bestemt af de sarlige forhold $i$ Den Tredje Verden $i$ almindelighed og $i$ Bangladesh $i$ saerdeleshed $?^{4}$ Det er vigtigt her at notere sig, at det er Grundtvigs pædagogiske tanker og $i k k e$ højskoletraditionen (dvs. virkningshistorien), der spørges til.

Resten af bogen bliver nu Bugges svar på spørgsmålet, idet han peger på, at der er tre faser i de fremmedes arbejde med Grundtvigs tanker: 1) en udvaelgelse i Grundtvigs store produktion af tanker, 2) en tilpasning af disse udvalgte tanker til den fremmede praksis og 3) en udvikling i Grundtvig-tolkningen. Det er herefter udviklingen i Grundt- 
vig-tolkningen, der er fokus for Bugges analyse, og han ordner analysearbejdet i seks afsnit:

1. Parallelitet mellem Danmark i midten af den 19. århundrede og nutidens Bangladesh

2. Folkeoplysning

3. Skolen for livet

4. Levende vekselvirkning

5. Frihed

6. Nye prioriteringer.

Det er en meget spændende analyse, som demonstrerer Bugges suveræne viden om Grundtvigs pædagogiske tanker, og jeg synes analysen bringer orden i mange spørgsmål og problemstillinger vedrørende en overføring af Grundtvigs tanker til et tredjeverdensland. Jeg vil ikke mindst fremhæve afsnittet om frihed, hvor også den latinamerikanske pædagog og tænker Paulo Freire drages ind i analysen. Paulo Freire har ifølge Bugge været kendt i mange u-lande, længe før man har fået kendskab til Grundtvig, så derfor er en sammenstilling af Grundtvig og Paulo Freire naturlig, og Freires frihedstænkning giver stof til en nytolkning af Grundtvigs frihedsbegreb. Bugge kalder selv sin sammenstilling af de to tænkeres frihedsbegreb en »foreløbig undersøgelse ${ }^{5}$. Man må håbe, at Bugge tager sig tid til senere at gøre undersøgelsen mere omfattende, for sammenstillingen mellem de to og inddragelsen af konkrete tekster (foreløbig mest fra Grundtvigs hånd) er uhyre spændende. En yderligere analyse vil givetvis kunne være med til at udvikle en (nødvendig) nutidig tolkning af Grundtvigs frihedsbegreb. Det er f.eks. bemærkelsesværdigt, at Bugge i analysen slet ikke udfolder det klart socialistiske udgangspunkt hos Freire og den betydning det har for Freires frihedsbegreb. Her må være et aspekt, som vil kunne udfordre det grundvigske frihedsbegreb, og artikler og bøger af folk som Ebbe Kløvedal Reich og Ejvind Larsen vil med fordel kunne inddrages $\mathrm{i}$ en sådan videre analyse.

Mens vi er ved noget af det, jeg mener mangler ved bogen, vil jeg også nævne min forundring over, at det religiøse aspekt hos Grundtvig inddrages så lidt, som det er tilfældet. Den bengalske forfatter og filminstruktør Tanvir Mokammel, som Bugge mange gange refererer til, understregede over for mig i en radiosamtale, at interessen for Grundtvig i Bangladesh i høj grad skyldes, at Grundtvig var så stærkt båret af sin religion, som han var. Efter Mokammels opfattelse var det egentligt inspirerende for skolefolkene i Bangladesh i forhold til Grundtvig, at han på samme tid havde nærmest socialistisk-demokratiske idealer om samfundet og var et stærkt religiøst menneske. Det var på mange måder også deres ideal at kunne kombinere religion og socialisme, men de savnede den religiøse dimension hos mange, der tænker pædagogik og demokrati sammen. Den fandt de altså hos Grundtvig - og i øvrigt også hos Freire, hvis tanker ligeledes er kendetegnet ved at religion, pædagogik og politik går op i en højere enhed.

Heller ikke i Bugges sammenstilling af Grundtvig og Freire berøres det fælles religiøse aspekt hos de to tænkere.

Det er tydeligt, at Bugges interesse og store viden i højere grad findes inden for Grundtvig-tolkningen end inden for højskole-tolkningen. Bogen bliver således ikke (hvad han bestemt heller ikke hævder) en analyse af, hvordan højskoleideen har omsat sig til og udviklet sig i den tredje verden. På det område - altså som skolebeskrivelse - bliver den én blandt andre vigtige beskrivelser af, hvad der faktisk foregår. Alligevel 
er det en fremragende lille bog K.E. Bugge har skrevet, og dens analyser bringer forskningen om "Grundtvig-eksport» et stort skridt videre.

\section{Noter}

1. Lilian Zøllner 1994, p. 7 (se ovf.)

2. p. 9 .

3. p. 39-40.

4. p. 61-62.

5. p. 70 . 